\title{
A Discourse-Historical Approach to Populism in the Right-Wing Discourse on Immigration
}

\author{
${\text { Abdulfattah } \text { Omar }^{1 \& 2} \text {, Wafya Ibrahim Hamouda }}^{3} \&$ Mohammed Aldawsari ${ }^{1}$ \\ ${ }^{1}$ Department of English, College of Science \& Humanities, Prince Sattam Bin Abdulaziz University, Saudi \\ Arabia \\ ${ }^{2}$ Department of English, Faculty of Arts, Port Said University, Egypt \\ ${ }^{3}$ Departments of Foreign Languages, Faculty of Education, Tanta University, Egypt \\ Correspondence: Abdulfattah Omar, Department of English, College of Science \& Humanities, Prince Sattam \\ Bin Abdulaziz University, Al-Kharj, Riyadh, 11942, Saudi Arabia. E-mail: a.abdelfattah@psau.edu.sa
}

Received: January 18, 2020 Accepted: March 2, 2020 Online Published: March 21, 2020

doi:10.5539/ijel.v10n3p151 URL: https://doi.org/10.5539/ijel.v10n3p151

\begin{abstract}
This study is concerned with investigating the implications of the new nationalist and populist discourse of the far right-wing movements to immigration in different Arab countries, with a focus on Egypt, Lebanon, and Jordan. For this purpose, the study is based on a corpus of different genres, including political speeches, newspaper articles, as well as social media posts and comics. Critical Discourse Analysis (CDA) is used in order to explore speakers' ideologies and how rhetoric and discursive strategies are employed to influence public opinion and persuade citizens about certain views and policies and even prompt them to take the desired action. Results indicate that the new nationalist and populist discourse adopted by different politicians and far right-wing parties and movements have negative impact on the rights of migrants and refugees in Arab countries. Migrants and refugees are used as scapegoats for political gains. They are blamed for all social, economic, and political challenges and crises these countries are suffering today. Right-wing movements are embedding some hidden ideologies in their political discourse that are related to the hate and rejection of migrants and refugees. It can also be concluded that the increasing popularity of anti-immigration movements and radical right-wing political leaders hint at the influence of the nationalist and populist discourse on the public opinion in their countries. Populist discourse has led to fear and rejection of the "Other", and even to racist acts and xenophobia.
\end{abstract}

Keywords: Critical Discourse Analysis (CDA), immigration, nationalist discourse, populism, right-wing movements

\section{Introduction}

The recent years have witnessed the widespread of concepts of nationalism and populism in the discourse of many political leaders and activists in different Arab countries due to the unprecedented increase in the number of immigrants and refugees as a result of what is referred to as Arab Spring: revolutions, conflicts and even civil wars in different Arab countries (Alshoubaki \& Harris, 2018). In the face of this wave of immigrants, many political leaders and thinkers have promoted concepts of national identity which ultimately resulted in hostile attitudes towards immigration. In spite of what some refer to as noble ends of this discourse in giving priority to the domestic and security issues and preserving the national identities and cultures, such discourse usually assumes that the rights of migrants and refugees come at the nation's expense which consequently has negative impact on the lives and rights of the migrants and refugees in these countries. In so doing, right-wing movements employ different discursive strategies of persuasion in order to promote their ideologies, convince people about certain views and even prompt them to take the desired action. In light of this argument, this study is concerned with exploring the discursive persuasive strategies and ways certain ideologies are used and attitudes are produced, disseminated, inculcated and naturalized through this emerging kind of discourse in the Arab countries. The study asks the following research questions. First, how are immigrants and refugees discursively constructed in the discourses of right-wing Arab politicians, journalists, writers, and citizens between 2013 and 2018 ? Second, what are the hidden ideologies of the right-wing political leaders and activists when talking about the migration issue? In other words, how ideologies are produced and reflected in the new nationalist and populist discourse? Finally, what is the role of nationalist and populist discourse in the production and reproduction of 
racist discourse and even hate speeches? In order to address the research question, a corpus is built where data is derived from 300 sources representing different genres including political speeches, newspaper articles, as well as social media posts and comics between 2013 and 2018. For data analysis CDA methods are used.

\section{Literature Review}

The recent years have witnessed an increasing interest in what is known as nationalist and populist discourse due to the focus on immigration and minority issues (Nugent, 2013; Wodak, 2015; Wodak, Mral, \& KhosraviNik, 2013). The term populism is repeated with every ballot, from Brexit to the Trump speeches, analyses and political commentary before each election either in Arab or European countries. Apart from the historical connotations of the term, populism is now considered to be a part of the right-wing political thought and discourse (Wodak et al., 2013). The literature suggests that populist and nationalist discourse has been increasingly employed over the recent years in political debates and election campaigns as clearly seen in the last US Presidential elections and the discussions and debates over Brexit from the European Union. In spite of its frequent use, it is still 'difficult to have a universally accepted definition of the term' (Macaulay, 2018; Wodak, 2015). Populist discourse can be defined as a political speech directed at the popular classes, based on criticism of the regime, its officials and the elites (Muller, 2016). Although there is no agreement on defining the term, it is almost agreed that populist discourse is a form of public discourse concerned with challenging traditional and established democratic institutions (Macaulay, 2018; Tenorio, Benitez-Castro, \& De Cesare, 2019).

Populist discourse is a form of 'public discourse, whereby the speaker establishes the power to take control' and influence his recipients whether they are individuals or political parties. Populist discourse is generally associated with both the ruling authority and/or opposition leaders in societies and it is one of the most important mechanisms employed by politicians, political leaders, and decision-makers in almost all the communities whether developed or developing (Hidalgo-Tenorio, 2019; Wodak, 2015). The aim of the populist discourse, Chilton (2004) argues, is to convince the audience and the public of the speaker's arguments, to accept their ideas and take them for granted. For this purpose, speakers usually use different linguistic and logical devices to convince the public. In other words, the use of logical and linguistic devices is usually linked to the strategic objectives of populist discourse. Pajnik and Sauer (2017) add that these are used by speakers to achieve different functions including hiding the truth, influencing the audience and recipients, expressing refusal and rejection, and 'providing legitimacy' for a particular group or party.

Populist discourse has several unique characteristics. First, flexibility and adaptability according to the context or place of the speech, whether it is released by the majority or the opposition (Bobrowski, 2004). This flexibility is demonstrated in the following ways: (a) praising, criticizing or objecting to prevailing politics in society, depending on attitude and interest, or (b) defending the political programs in the country, and the resulting political tests, or refuting them and presenting alternative scenarios (Charteris-Black, 2018). Second, populist discourse is characterized by optimism and confidence. Political speakers, Van Dijk (2002b) indicates, usually give their recipients hope, or provide a political vision contrary to 'the rhetoric'. Third, populist discourse is associated with the representation of ideologies in an integrated and coherent way. Fourth, power and hegemony are integral parts of populist discourse. It is also true that speakers frequently tend to remind the audience of their achievements and political accomplishments (Gee, 2007; Van Dijk, 2002a). Fifth, rhetoric as it has a remarkable impact on the recipients, audience and the public (Charteris-Black, 2018). Sixth, political speeches are generally long and full of repetition of words, phrases and sentences to emphasize ideas and foreground embedded messages in a way that influences the recipients and leads them to accept what is conveyed by the speaker (Charteris-Black, 2018; Wodak, 2017). Finally, euphemism and political correctness are significant features of political discourse. Politicians employ euphemism and political correctness strategies in order to come closer to the different speech communities to evade rejection and disapproval (Anstead, 2018; Muller, 2016; Wodak, 2015).

In exploring the embedded ideologies and discursive strategies employed by the speakers, CDA has been adopted in numerous studies for its potentials in investigating different social and political problems associated with this kind of discourse and exploring their effects and implications on countries and societies (Reisigl \& Wodak, 2005). It is the function of CDA to expose, uncover, and unmask the hidden meanings and implied messages within texts. CDA is thus appropriate to discover the inconsistencies, contradiction, and paradoxes within this discourse. Van Dijk (1993) suggests that discourse studies have paid special attention to the problems of race and discrimination in terms of power relations. He contends that CDA approaches seek "to show that the various elites (e.g., in politics, the media, academia, education and corporate business) play a prominent role in the reproduction of racism, and so on, sometimes subtly, through the respective discourse genres to which they have access". Likewise, Wodak (2015) indicates that during the 1990s work on racism increasingly made use of 
such discourse-analytical notions. Racial discrimination and immigration are among the most extensive and widespread fields of critical research on discourse and language that have been carried out within discourse studies. In On the Analysis of Parliamentary Debates on Immigration, Van Dijk (2000b) explores the discursive mechanisms involved in the reproduction of racism, and the way racism is challenged in Western Europe. To achieve his purpose, he examined some diverse discourse properties as intonation, word order, clause structure, sentence meaning, presuppositions, local coherence, global topics, lexical style, metaphors, overall organization, speech acts, turn allocation, and interactional strategies. This suggests that Van Dijk has combined textual features with non-textual features in his analyses. Following his tradition, Reisigl and Wodak (2005) give a high priority to social and political problems in general and the racism issue in particular. In Discourse and Discrimination, they address the problems of new identity, nationalism, immigration, and anti-Semitism in the political speeches of the Austrian officials and in the parliamentary debates. Concerning the anti-Semitism issue, they observed that anti-Semitism prejudices are almost universal in Austria. They are found in the speeches of the politicians, in parliamentary debates, everyday discourse, and even on conversations on the street. They concluded that "the Austrian Nazi past seems to have started to grow". In the investigation of the political discourse on immigration and new nationalism, the two authors address the Austria First Petition of Jorg Haider, offering an elaborate analysis. They adopt the historical approach that has helped trace a part of the drastic development of anti-foreigner discourse in the Western tradition. They assume that the search for a new identity is not merely located in Austria. Rather, it is a supranational issue. Its universality is due to the widespread of globalization effects which bring with them the notions of nationalism, ethnicism, xenophobia, and racism. Reisigl and Wodak think that the analysis of political discourse must be carried out in several co-occurring dimensions: grammatical, pragmatic, prosodic, sequential, socio-interactional, rhetorical and ideological.

In spite of the extensive research on populist and nationalist discourse in Europe and Western countries (Van Dijk, 2000a, 2002a, 2014; Wodak, 2017; Wodak \& Busch, 2004), there is a lack of literature on nationalist discourse studies in Arab countries in spite of the increasing problems associated with this discourse in different Arab countries. This study seeks to address this gap in the literature through exposing, uncovering, and unmasking the hidden meanings, discursive strategies, and ideologies within these discourses.

\section{Methodology}

This study adopts CDA methods in order to explore how rhetoric and linguistic devices are employed by right-wing politicians and radical movements in order to influence the public opinion and citizens and convey their ideologies. The rationale is that CDA offers good avenues to examine the way language functions in social and political practice since the language used in political and media contexts, referred to as political and media discourses, embodies specific views of reality. These discourses are thus inseparable from social, economic and political factors. It is also true that language usage is not merely an effect or reflex of social organization and processes; it is a part of the social process (Fowler, 1979). The claim is that political and media discourses constitute social meanings and thus social practices. CDA is therefore appropriate for describing the social, interpersonal and ideological functions of linguistic constructions. CDA can be usefully used to explore the embedded messages conveyed in the speeches of the right-wing populist politicians in the Arab countries. In other words, it is appropriate for exploring the hidden ideologies, positions, and perspectives of politicians and speakers (Hidalgo-Tenorio, Benítez-Castro, \& De Cesare, 2019).

Wodak and Meyer (2001) assume that critical approaches to discourse tend to find the larger discursive unit of text to be the basic unit of communication. They deal with discourse as an embodiment of man in his relations with existing institutions and in a historical context leads to a discourse towards deeper and influential research fields. Many social sciences researchers go on to say that the current stage is considered to be the stage of prosperity of the discourse analysis studies. There has been an increasing interest in CDA approaches, at the expense of a lack of interest in the content analysis approach, given the great explanatory potential and the ability to directly relate to the sociological context. Fairclough (2013) agrees that CDA approaches seek to expose the power exercised on the cognitive models consumed by the discourse. He explains that CDA is the 'actual medium to devote the ambitions of hegemony at the social level, and it controls the convictions and choices. He adds that CDA focuses on the description of textual practice, analysis of rhetorical interaction, and critique of social practice. In this way, Rogers (2011) argues that the objective of the CDA is to reveal the power exercised by dismantling the linguistic structures of the texts and their internal linguistic networks, analyzing the contextual elements and interactive relationships among the participants, to identify the names, sites, and ideological references; and exposing the "latent power behind linguistic choices at the social level. Therefore, what goes beyond this approach earlier in the theory of discourse analysis, is to study the use of deceptive language that serves the ideologies, and the desire to control the decision areas in the mental structures of the 
target groups, and not only to analyze content only. For this reason, Bloor and Bloor (2013) indicate that critical approaches to discourse are now widely applied in the 'media, religious discourse, commercial advertising, racism, oppression of minorities, social oppression, mass communication, school and university education, economics and international relations. In this regard, they address different and numerous societal and political problems that affect the life of citizens and people. In order to explore concepts of ideology, power, hegemony, social practice, and social activism within the selected data, CDA is used. This is an integrated model that combines both textual constituents and contextual considerations is used. Three analytical methods are combined: describing textual practice, analyzing rhetorical practice, and interpreting social practice (Van Dijk, 2014).

For the purposes of this study, corpus-based methods are used (Baker, 2006). The rationale is that corpus-based methods are appropriate for investigating the discursive construction of the issues of immigrants and refugees in the Arab countries through the identification and analysis of collocation patterns of the words and phrases associated with immigrants and refugees. A corpus is thus built where data is derived from 300 sources representing different genres including political speeches, newspaper articles, as well as social media posts and comics. The corpus is divided into two subcorpora. Electronic websites (including the journal websites, blogs, and YouTube) are used for deriving the data. The first subcorpus includes the political speeches and newspaper articles of political leaders, decision makers, thinkers, writers, and journalists. The second one includes the comments of readers and the public on the political leaders' and journalists' discourse with the purpose of exploring the perlocutionary force of the nationalist and populist discourse on citizens and public opinion. Sampling methods are used in order to derive texts about the migrants and refugees in the three selected Arab countries. The study is limited to the discourses produced between 2013 and 2018.

\section{Analysis and Discussion}

Based on the coded data in the first subcorpus, some key word patterns were identified. These include terrorism, illegal immigration, unemployment, inflation, violence, and political unrest, which can be considered as themes of this study. This study labeled these discourses as outbursts of politicians and revealed their nationalistic policies as the themes identified for this study. These themes have been subject of the sampled political speeches referring to migrants and refugees trying to escape the dangers of war, oppression, social conflicts from their native countries. Table 1 illustrates the frequency of these themes in the data. For instance, there were a total of 2164 references from 150 political speeches and news articles which unveiled the rhetorical descriptions of refugees and immigrants. The use of such rhetoric enabled the speakers/writers to frame the problem of refugees exactly in the manner as they intended. Table 1 further exhibits a professional use of persuasive strategies and other lexical attributions that unequivocally convince the masses of the "threat" that refugees might pose upon their lives.

Table 1. Identified key word patterns and themes

\begin{tabular}{|c|c|c|}
\hline Themes & Frequency & Examples \\
\hline \multirow[t]{3}{*}{ Unemployment } & 781 & "They are taking our jobs". \\
\hline & & "no jobs for our own people... there are millions extra to feed" \\
\hline & & Jobs, jobs, jobs.... it's for our people, and not for foreigners" \\
\hline \multirow[t]{4}{*}{ Terrorism } & 532 & "they will gun down our own people" \\
\hline & & "they come here to terrorize our people" \\
\hline & & "support Muslim Jihadists" \\
\hline & & "Immigration opens the door for potential terrorists to enter our country" \\
\hline \multirow[t]{2}{*}{ Violence and crime } & 329 & "Crimes are everywhere" \\
\hline & & "They are threatening our societal security" \\
\hline \multirow[t]{2}{*}{ Inflation } & 247 & "Rents cannot be affordable this way. Prices have doubled over the last two years" \\
\hline & & "Home prices have doubled because of Iraqi and Syrian immigrants". \\
\hline \multirow[t]{2}{*}{ Illegal immigration } & 154 & "The good times for illegals are over." \\
\hline & & $\begin{array}{l}\text { "Employers should not violate labor laws. Illegal immigrants should not be hired in } \\
\text { any way". }\end{array}$ \\
\hline \multirow[t]{6}{*}{ Political unrest } & 121 & "they unsettle us politically" \\
\hline & & "Where is the system?" \\
\hline & & 'Immigrants are a societal threat to our political system' \\
\hline & & "This mess will end up with a social disintegration" \\
\hline & & "Syrian and Sudanese refugees are betraying our political system" \\
\hline & 2164 & \\
\hline
\end{tabular}


As indicated in Table 1, the issue of unemployment is the most highly associated with immigrants and refugees. Different politicians and writers have attributed the problem of unemployment to the flow of immigrants to their countries. Speakers stressed that immigration has a negative impact on labor market. They indicate that migrants and refugees take the jobs of native-born workers. Concepts of terrorism come second in association with migrants and refugees. In Egypt, Syrian refugees were accused of supporting terrorism after the June events in 2013 that led to the overthrow of the Muslim Brotherhood regime and the detention of the Egyptian President at that time Mohamed Morsi. Many politicians, political thinkers, journalists, and media anchors accused the Syrians of supporting Muslim jihadists in Egypt. In an article by Nabeel Naeem, the founder of the Jihadist movements in Egypt in the 1990s, he accused the Syrians of supporting the Muslim Brotherhood in Egypt through terror acts. He blamed them for terror incidents in Sinai and different parts of Egypt. Similarly, the Lebanese politician Gebran Bassil repeatedly accused the Syrian refugees in Lebanon indicating that they are a threat to the existence of Lebanon and that they support global terrorism. In Jordan, the flow of Syrian refugees was also considered as a threat to national security and the main reason for breeding terror acts in Jordan and different neighboring Arab countries. In December, 2016, the Jordanian authorities to close the borders and prevent the Syrian refugees from crossing the borders in spite of the 'humanitarian positions' of these refugees (Alshoubaki \& Harris, 2018).

A collocation pattern analysis also revealed that migrants and refugees were associated with other economic and political problems. These included inflation, unemployment, poverty, illegal immigration, violence, and political unrest. To support their arguments and ideologies, speakers used different discursive strategies including Positive Self Presentation on one hand and Negative Other Presentation, on the other hand. Table 2 presents the Semantic Preference/collocates of political speeches. As indicated in Table 2, 16 populist sources made use of 98 references to emphasize 'our' good actions while 14 sources made use of 145 references to emphasize 'others' bad actions.

Table 2. Positive self-representation vs. negative other representation

\begin{tabular}{|c|c|}
\hline Positive Self Representation 'our good actions' & Negative Other Representation 'others' bad actions' \\
\hline Sources $=16$ & Sources $=14$ \\
\hline $\begin{array}{l}\text { citizen, national, justice, economy, security, courts, } \\
\text { mainstream, stability, voters, policy, culture, politics, and } \\
\text { securing our borders' }\end{array}$ & $\begin{array}{l}\text { thieves, aliens, foreigners, illegal immigrants, criminals, random } \\
\text { and messy, unemployment, protesters, refugees, terrorists, foes } \\
\text { to nobleness, threat to the state, refugee camp, tax-evasion }\end{array}$ \\
\hline
\end{tabular}

The first ideology was pertinent in the representation of the 'self' as represented in almost all sampled speeches and news articles. The first-hand collection of collocates exemplified in Table 2 refers to the vocabulary of politics, law and order, immigration, foreign policy, war and community; presenting the politicians in these countries in overall a positive manner. The rhetoric of so-called Western ideals of Justice, liberty, freedom, and democracy are also represented in these collocations. The frequency of such an ideology in sematic preferences also acts as the discourse for its appropriation and rationalization in the situation under study.

The second ideology was pertinent in the presentation of the 'other' in a negative way. The political rhetoric in the speeches not only presented the 'self' of Egypt, Jordan, and Lebanon in a civilized manner, but showed the 'other', the migrants and the refugees in a highly negative manner. Table 2 also presents the empirical findings of this ideology. Colocations of these terms show the use of such vocabulary items that are mostly used for terrorists, militants, extremists, militias, fundamentalists and rebels. The corpora that have been built up with the negative 'other' presentation unanimously and consistently attempt to prove the refugees and immigrants as either militants or Islamic fundamentalists. This reflects the negative attitudes of the press and media for migrants and refugees in these countries. It can also be suggested that the refugee issue received serious media attention in the three Arab countries of Egypt, Jordan, and Lebanon where different politicians, journalists, and writers used stereotyped and rhetorically rich speeches to create paranoia among the citizens in their countries. The issue of migrants and refugees in these countries has been given a meaningful 'media voice' in populist speeches and nationalistic narratives. The speeches are classified under what was so-called nationalist and populist discourse, but a clear dichotomy was seen in the people. Aggressive tone was noticed in the masses for and against immigrants and refugees. It was evidenced that public response was mixed, both of discontentment and pathos, anger as well as sympathy, political rights versus human rights, nationality against allowing refuge and shelter.

Amidst this turmoil, the nationalists and the populists seek electoral advantages from the immigration issue. In 
Lebanon, for instance, the Syrian refugees were used by politicians for political gains in the parliamentary elections in 2018. In a press conference for the Lebanese Foreign Minister Gebran Bassil with his German counterpart in September 2018, he asked for the return of the Syrian refugees into their homeland as they are a burden on the Lebanese economy and the limited job opportunities in Lebanon. He stressed the term "Lebanon for Lebanese" indicating that job opportunities should go only to the Lebanese. This kind of discourse reflects his hidden ideology of not welcoming migrants and refugees in spite of their humanitarian position. He even called for forming an "anti-immigration front" to save Lebanon from the threats of immigrants and refugees. His discourse thus reflects his hostile attitude towards immigration. Immigrants and refugees are used for political gains.

The analysis also indicates that other problems of inflation, illegal immigration, violence, and political unrest have collocates with immigrants and refugees. It should be noted, however, that the populist discourse of the anti-immigration groups is based on lies and false information. For example, there is no evidence-based research that supports the claims of politicians and media that immigration has negative impacts on employment. On the contrary, many reports refer to a boom in different industries in Egypt due to the inflow of Iraqi and Syrian refugees' capital (Noureldin, 2017). Different reports also indicate clearly that migrants and refugees in Lebanon have positive impacts on the economic position of the country (David, Marouani, Nahas, \& Nilsson, 2019). Furthermore, politicians, journalists, and media anchors also do not mention hate crimes, rape, abuse, and sexual harassment immigrants and refugees usually suffer. It can be claimed thus that populist discourse is usually based on false information and lies in order to deceive the public and voters from one side and to convey the hidden ideologies of the speakers.

In order to explore the influence of the discourse of far right-wing parties over the beliefs and opinions of the public, a subcorpus was built of the readers' comments on the speeches and news articles produced by politicians, writers, journalists, and media anchors. Comments indicate clearly that many people have been influenced by the nationalist and populist discourse as indicated in the reproduction of this kind of discourse. These are just example: 'The army has to secure our national borders and end immigration', 'Syrian immigrants cost us healthcare and education', 'Money spent on Syrians should go to the Egyptian people', 'They are taking our jobs', 'They should be deported', 'Our public schools and hospitals are not performing well due to the burden of Iraqi and Syrian refugees', 'They are killing our sons and people in Sinai', 'We need a good legal apparatus for preventing tax-evasion crimes committed by Syrians and refugees', 'They make their own businesses and are unwilling to contribute to the national economy', 'They use our money in supporting terrorism', 'Violence is growing in our neighborhood', 'Immigrants are really random and messy', 'Stop immigration for the sake of our education and health systems; 'Protect the Jordanians and save their jobs'. 'Refugees are not getting in compliance with our laws', 'Immigrants must return to their native countries in order to ensure security', 'They belong to the Muslim Brotherhood', 'They are bombing the Egyptians', 'Immigration is a crisis for our country', and 'Immigrants add unbearable costs to our education and healthcare systems'.

It can be seen that migration and migrants collocate many social and economic problems including unemployment, terrorism, violence, and lack of security. The claim here is that racist discourse is reproduced by the public and readers. It is even claimed that the nationalist and populist discourse caused and even sometimes forced the government officials in Egypt, Jordan, and Lebanon to adopt policies and procedures against the interests of immigrants and refugees. These governments thus used security rhetoric to legitimize their anti-refugees' policies and securitizing their borders. This is supported by Van Dijk's argument that government officials themselves reproduce racism when talking about the issues of immigration and refugees. In his analysis of discourse and racism, Van Dijk (1997) examines how politicians speak about race and ethnic relations, immigrants, refugees, and other minorities. The author draws upon examples "taken from debates in the United States, Great Britain, Germany, France, and the Netherlands that were held between the early 1980s and 1990s". One of the findings of the work is that politicians themselves reproduce racism when talking about the issues of immigration and refugees. The speeches of the politicians in the parliamentary debates, and more specifically when defining refugees, immigrants, or minorities as the main cause of many social problems reflect quite clearly their racist opinions and practices. Van Dijk found out that "the various elites play a major role in the discursive reproduction processes of the system of racism". The impact of the nationalist and populist discourse on immigrants and refugees should not be underestimated. Different reports stress that the wave of attacks on refugees in different Arab countries is unprecedented, and the situation is fueling the rise of the extreme right-wing discourse, which is keen to link immigrants and refugees to the spread of extremism and the decline of jobs available in these countries. Reports indicate that the scale and range of attacks on refugees in these countries are witnessing unprecedented expansion, coinciding with the rise of far-right rhetoric across the 
continent. These can be attributed to the lies in the populist discourse. Many citizens have come to be convinced that migrants and refugees are stealing their jobs and causing different problems to their economies. Analysts and observers indicate that the rise of the extreme right and radical movements have increased the fears of immigrants and that the success of right-wing parties in reaching political decision-making positions will increase the level of racism and hatred against them.

\section{Conclusion}

This study addressed the implications of the nationalist and populist discourse to immigration in the Arab countries with a focus on Egypt, Jordan, and Lebanon. It was evident that the issue of migration has been one of the most important topics addressed by radical and right-wing movements and parties in these countries over the recent years. This was reflected in recent parliamentary elections in these countries where the radical movements and right-wing parties heavily armed the nationalist and populist discourse. The rejection of the 'Other' and even demands of the closure of the borders in the face of migrants and refugees in spite of the humanitarian position of the migrants and refugees was seen. They are also calling for the revision of the immigration laws. The migration issue is used for making political gains. The recent years have witnessed an increasing dominance of the far right-wing movements in different Arab countries including Egypt, Jordan, and Lebanon. This is partly attributed to the nationalist and populist discourse manipulated by political leaders who usually blame migrants and refugees for the security, social, and economic problems in these countries. In this context, it can be claimed that the nationalist and populist discourse embeds different hidden ideologies for political gains. In other words, right-wing movements are embedding in their political discourse some hidden ideologies that are related to the hate and rejection of migrants and refugees. It can also be concluded that the increasing popularity of anti-immigration movements and radical right-wing political leaders hint at the influence of the nationalist and populist discourse on the public opinion in their countries. Populist discourse has led to fear and rejection of the "Other", even to racist acts and xenophobia.

\section{Acknowledgments}

We take this opportunity to thank Prince Sattam Bin Abdulaziz University in Saudi Arabia alongside its Deanship of Scientific Research, for all technical support it has unstintingly provided towards the fulfillment of the current research project.

\section{References}

Alshoubaki, W., \& Harris, M. (2018). The impact of Syrian refugees on Jordan: A framework for analysis. Journal of International Studies, 11(2), 154-179. https://doi.org/10.14254/2071-8330.2018/11-2/11

Anstead, N. (2018). The Idea of Austerity in British Politics, 2003-2013. Political Studies, 66(2), 287-305. https://doi.org/10.1177/0032321717720376

Baker, P. (2006). Using Corpora in Discourse Analysis. Bloomsbury Academic.

Bloor, M., \& Bloor, T. (2013). The Practice of Critical Discourse Analysis: An Introduction. Taylor \& Francis. https://doi.org/10.4324/9780203775660

Bobrowski, C. L. (2004). Populist Discourse: An Adornian Rhetorical Analysis of the Emotional Appeal of Pauline Hanson's One Nation. University of Tasmania.

Charteris-Black, J. (2018). Analysing Political Speeches: Macmillan International Higher Education.

Chilton, P. A. (2004). Analysing Political Discourse: Theory and Practice. London; New York: Routledge. https://doi.org/10.4324/9780203561218

David, A., Marouani, M. A., Nahas, C., \& Nilsson, B. (2019). The economics of the Syrian refugee crisis in neighbouring countries: The case of Lebanon. Economics of Transition and Institutional Change, 28(1), 89-109. https://doi.org/10.1111/ecot.12230

Fairclough, N. (2013). Critical Discourse Analysis: The Critical Study of Language. Taylor \& Francis. https://doi.org/10.4324/9781315834368

Fowler, R. (1979). Language and Control. Routledge \& K. Paul.

Gee, J. P. (2007). Social linguistics and literacies: Ideology in discourses. Routledge. https://doi.org/10.4324/9780203944806

Hidalgo-Tenorio, E., Benítez-Castro, M. Á., \& De Cesare, F. (2019). Populist Discourse: Critical Approaches to Contemporary Politics. Taylor \& Francis. https://doi.org/10.4324/9780429026751 
Macaulay, M. (2018). Populist Discourse: International Perspectives. Springer International Publishing. https://doi.org/10.1007/978-3-319-97388-3

Moffitt, B. (2016). The Global Rise of Populism: Performance, Political Style, and Representation. Stanford University Press. https://doi.org/10.2307/j.ctvqsdsd8

Muller, J. W. (2016). What Is Populism? University of Pennsylvania Press. https://doi.org/10.9783/9780812293784

Noureldin, O. (2017, May 15, 2017). Syrian refugees contributed over $\$ 800 \mathrm{mln}$ to Egypt's economy: UNDP report. Egypt Independent. Retrieved from https://egyptindependent.com/syrian-refugees-contributed-800-mln-egypts-economy-undp-report/

Nugent, W. (2013). The Tolerant Populists, Second Edition: Kansas Populism and Nativism. University of Chicago Press. https://doi.org/10.7208/chicago/9780226054117.001.0001

Pajnik, M., \& Sauer, B. (2017). Populism and the Web: Communicative Practices of Parties and Movements in Europe. Taylor \& Francis. https://doi.org/10.4324/9781315101958

Reisigl, M., \& Wodak, R. (2005). Discourse and Discrimination: Rhetorics of Racism and Antisemitism. Taylor \& Francis. https://doi.org/10.4324/9780203993712

Rogers, R. (2011). An Introduction to Critical Discourse Analysis in Education. Taylor \& Francis. https://oi.org/10.4324/9780203836149

Tenorio, E. H., Benitez-Castro, M. A., \& De Cesare, F. (2019). Populist Discourse. Taylor \& Francis.

Van Dijk, T. A. (1993). Principles of Critical Discourse Analysis. Discourse \& Society, 4(2), 249-283. https://doi.org/10.1177/0957926593004002006

Van Dijk, T. A. (1997). Political Discourse and Racism: Describing Others in Western Parliaments. In S. H. Riggins (Ed.), The Language and Politics of Exclusion. Others in Discourse (pp. 31-64). Thousand Oaks, CA: Sage.

Van Dijk, T. A. (2000a). News racism: A Discourse Analysis Approach. In S. Cottle (Ed.), Ethnic Minorities and the Media (pp. 33-49). Milton Keynes, UK: Open University Press

Van Dijk, T. A. (2000b). On the analysis of Parliamentary Debates on Immigration. In M. Reisigl \& R. Wodak (Eds.), The Semiotics of racism. Approaches to Critical Discourse analysis (pp. 85-103). Vienna: Passage Veralg.

Van Dijk, T. A. (2002a). Political discourse and ideology. Anàlisi del discurs polític, 15-34.

Van Dijk, T. A. (2002b). Political discourse and political cognition (p. 203). Politics as text and talk: Analytic approaches to political discourse. https://doi.org/10.1075/dapsac.4.11dij

Van Dijk, T. A. (2014). Discourse and Knowledge: A Socio-cognitive Approach. Cambridge Cambridge University Press. https://doi.org/10.1017/CBO9781107775404

Wodak, R. (2015). The Politics of Fear: What Right-Wing Populist Discourses Mean. Los Angles; London; Washington: SAGE. https://doi.org/10.4135/9781446270073

Wodak, R. (2017). Discourse and politics: The rhetoric of exclusion The Haider Phenomenon (pp. 33-60). Routledge.

Wodak, R., \& Busch, B. (2004). Approaches to Media Texts. In J. Downing, D. McQuail, P. Schlesinger, \& E. Wartella (Eds.), Handbook of Media Studies (pp. 105-123). Thousand Oaks, CA: SAGE Publications. https://doi.org/10.4135/9781412976077.n6

Wodak, R., \& Meyer, M. (2001). Methods of Critical Discourse Analysis. SAGE Publications. https://doi.org/10.4135/9780857028020

Wodak, R., Mral, B., \& KhosraviNik, M. (2013). Right-Wing Populism in Europe: Politics and Discourse. Bloomsbury Academic.

\section{Copyrights}

Copyright for this article is retained by the author, with first publication rights granted to the journal.

This is an open-access article distributed under the terms and conditions of the Creative Commons Attribution license (http://creativecommons.org/licenses/by/4.0/). 